\title{
Anatomic Site Code
}

National Cancer Institute

\section{Source}

National Cancer Institute. Anatomic Site Code. NCI Thesaurus. Code C93504.

A coded value specifying the anatomic site(s) or system. 